\title{
Marine microbenthic community structure regulated by nitrogen loading and grazing pressure
}

\author{
Helmut Hillebrand ${ }^{*}$, Boris Worm, Heike K. Lotze \\ Institut für Meereskunde, Abteilung Meeresbotanik, Düsternbrooker Weg 20, 24105 Kiel, Germany
}

\begin{abstract}
Generalisations on the combined effects of consumers and resources on autotrophs in aquatic food webs largely rely on freshwater studies. In this study, we tested these general concepts with marine benthic microalgae, which are important components of coastal food webs. We manipulated nitrogen availability and herbivore presence in a factorial field experiment in the Western Baltic Sea. Moreover, we investigated how herbivore control varied among 3 sites and 2 seasons and tested for trophic cascades by enhancing demersal fish density at 2 sites. Nitrogen availability and herbivore presence had strong and antagonistic effects on microalgal biomass, species composition and diversity. Herbivores significantly reduced algal biomass, whereas nutrient enrichment led to an increase in biomass. Herbivore effects on microalgal biomass increased with increasing nitrogen availability, indicating a functional response of herbivores to nutrient enrichment. The response of microalgae at the species level suggested a trade-off between nutrient use and grazing resistance which appeared to be linked to algal growth form. Compared to other growth forms, large erect species were most responsive to both nitrogen loading and herbivory. Grazing reduced microalgal diversity at low nutrient supply, but enhanced it at high nutrient supply. Herbivore effects varied considerably among different sites and were stronger in spring than in summer. Manipulations of fish density during summer did not have any effects on microalgal community structure. In conclusion, our results demonstrate that herbivores and nutrients have strong and balancing effects on marine microbenthic community structure.
\end{abstract}

KEY WORDS: Periphyton · Herbivory $\cdot$ Species composition $\cdot$ Nutrients $\cdot$ Diversity

\section{INTRODUCTION}

The structure of plant assemblages is generally thought to be regulated by the interplay of consumers, resources and abiotic factors. Although benthic microalgae can have a pivotal role as primary producers in littoral communities (Daehnick et al. 1992, Pinckney \& Zingmarck 1993), the factors affecting microalgal community structure and diversity remain poorly studied in comparison to pelagic microalgae (Hillebrand \& Sommer 1997). Herbivory on epilithic microal-

\footnotetext{
*Present address: Erken Laboratory, University of Uppsala, Norr Malma 4200, 76173 Norrtälje, Sweden.

E-mail: helmut.hillebrand@ebc.uu.se
}

gae has been studied sporadically in the marine environment (Castenholtz 1961, Nicotri 1977, Hunter \& Russell-Hunter 1983, Sommer 1997, 1999a). These experiments indicated potentially predominant topdown control and differential influence of different types of herbivores on species composition and vertical structure of the algae. On the other hand, recent studies have demonstrated pronounced nutrient limitation in marine microphytobenthos and strong effects of experimental nutrient enrichment on species composition and diversity (Sundbäck \& Snoeijs 1991, Hillebrand \& Sommer 1997). The relative influence of nutrient and grazing effects on these communities has not yet been simultaneously assessed in marine environments. 
This scarcity of studies is contrasted by the thorough investigation of grazing effects on stream periphyton (reviewed by Steinman 1996). According to such studies, herbivores at natural densities can strongly reduce algal biomass (Hill \& Knight 1987, Steinman et al. 1987), change the physiognomy of the community by removing their upper layers (Lowe \& Hunter 1988, Steinman et al. 1991), and influence successional patterns (Tuchman \& Stevenson 1991). Simultaneous manipulation of nutrient supply and grazing revealed strongest effects on freshwater periphyton (Marks \& Lowe 1989, Rosemond 1993, Rosemond et al. 1993). However, it remains unresolved if conclusions derived from streams, which are characterised by a unique matrix of habitat constraints (Biggs et al. 1998), can be transferred to the marine microbenthos.

Within the context of a broader study of grazermacrophyte-nutrient interactions (Lotze 1998, Worm et al. 1999, 2000a, Lotze et al. 2000), we investigated the effect of grazing and nutrient enrichment on benthic microalgae in a factorial field experiment. We tested the following hypotheses: (1) Herbivores and nitrogen availability antagonistically control the biomass of epilithic microalgae, (2) Herbivores and nitrogen exert selective control by preferentially removing or favouring certain species or growth types, (3) The grazing effect differs on small temporal and spatial scales, and (4) The impact of herbivores on microphytobenthos is influenced by fish predation on herbivores (trophic cascade).

We conducted 3 field experiments to test these hypotheses. For Hypotheses 1 and 2, nutrient supply and grazer presence were experimentally manipulated at 1 site (nutrient $\times$ grazing experiment). For Hypothesis 3, grazer presence was manipulated at 3 similar sites (spring grazing experiment). For Hypothesis 4, fish density was experimentally increased (summer grazing experiment). Combining all experimental results for 1 site allowed us to analyse the temporal shifts in grazing effects (Hypothesis 3).

\section{METHODS}

Study site. The main study site was located at Maasholm, a sheltered broadening of the Schlei Fjord, Western Baltic Sea $\left(54^{\circ} 41^{\prime} \mathrm{N}, 10^{\circ} 00^{\prime} \mathrm{E}\right)$. The Schlei Fjord is a tideless, inshore water-system of glacial origin. Salinity ranges from 12 to 18 PSU in summer and 14 to 20 PSU in winter. Water temperature ranges from -1 to $2^{\circ} \mathrm{C}$ in winter and 16 to $25^{\circ} \mathrm{C}$ in summer. Nutrient concentrations at Maasholm

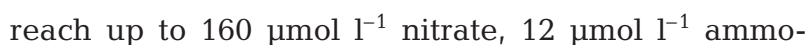
nium and $2 \mu \mathrm{mol} \mathrm{l}^{-1}$ phosphate from January to March (Schramm et al. 1996). From mid-May to mid-
August, ammonium and nitrate are largely depleted and typically remain close to the detection limit $(0.0$ to $0.3 \mu \mathrm{mol} \mathrm{l^{-1 }}$ ), whereas soluble reactive phosphate

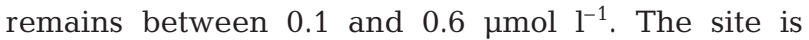
dominated by sandy substrata, with abundant rocks and boulders that sustain a community of epilithic macro- and microalgae, dominated by the large brown alga Fucus vesiculosus. Crustacean and gastropod grazers are abundant (Table 1), larger herbivores (urchins, limpets, fish) are absent because of the reduced salinity level of the Baltic Sea.

Nutrient $\times$ grazing experiment. We tested the effects of nutrient enrichment and grazing on biomass and species composition of benthic microalgae in a factorial field experiment in May 1998, since benthic microalgae in the Baltic Sea reach their seasonal maximum biomass during spring. All experiments were conducted in the shallow subtidal zone at 0.6 to $0.8 \mathrm{~m}$ water depth.

The presence of gastropod and crustacean grazers was manipulated with exclusion cages $(25 \times 25 \times$ $25 \mathrm{~cm}$ ), covered with a clear $1 \mathrm{~mm}$ polyethylene mesh

Table 1. Background data on grazer densities (individuals $\mathrm{m}^{-2}$ ) in field experiments. Grazer densities were evaluated within control plots (nutrient $\times$ grazing experiment and summer grazing experiment, $\mathrm{n}=16$ ) or by using $25 \times 25 \mathrm{~cm}$ frames (spring grazing experiment, $\mathrm{n}=10$ ). Idotea spp. are I. baltica and I. chelipes; Gammarus spp. are G. locusta, G. salinus and G. zaddachi

\begin{tabular}{|c|c|c|c|}
\hline $\begin{array}{l}\text { Experiment } \\
\text { Site }\end{array}$ & Grazer species & Mean & $(\mathrm{SE})$ \\
\hline \multicolumn{4}{|l|}{ Nutrient $\times$ grazing } \\
\hline \multirow[t]{6}{*}{ Maasholm } & Littorina saxatilis & 4031 & (408) \\
\hline & Littorina littorea & 0 & (0) \\
\hline & Hydrobia ulvae & 200 & (45) \\
\hline & Idotea spp. & 25 & (11) \\
\hline & Gammarus spp. & 0 & $(0)$ \\
\hline & Other & 10 & (5) \\
\hline \multicolumn{4}{|l|}{ Spring grazing } \\
\hline \multirow[t]{4}{*}{ Maasholm } & Littorina saxatilis & 1104 & $(370)$ \\
\hline & Littorina littorea & 41 & (17) \\
\hline & Idotea spp. & 444 & (96) \\
\hline & Gammarus spp. & 124 & (25) \\
\hline \multirow[t]{4}{*}{ Wackerballig } & Littorina saxatilis & 0 & (0) \\
\hline & Littorina littorea & 235 & (43) \\
\hline & Idotea spp. & 115 & (56) \\
\hline & Gammarus spp. & 56 & (31) \\
\hline \multirow[t]{4}{*}{ Geltinger Noor } & Littorina saxatilis & 325 & (119) \\
\hline & Littorina littorea & 10 & (4) \\
\hline & Idotea spp. & 35 & (10) \\
\hline & Gammarus spp. & 13 & $(7)$ \\
\hline \multicolumn{4}{|l|}{ Summer grazing } \\
\hline \multirow[t]{3}{*}{ Maasholm } & Littorina saxatilis & 63 & $(24)$ \\
\hline & Hydrobia ulvae & 312 & (57) \\
\hline & Idotea spp. & 13 & (9) \\
\hline Geltinger Noor & No data & & \\
\hline
\end{tabular}


('without grazer' treatment). In half these cages, 1 side was cut out to allow grazer access to the cages ('with grazer' treatment). The cages were brushed weekly in order to remove fouling algae from the mesh. Light intensity inside the cages was reduced by only $8 \%$ (Licor LI-192SA). To separate potential cage effects from grazer effects we conducted a control experiment whereby we compared open cages ('with grazer' treatment) with uncaged control plots.

Nutrient enrichment was performed with a commercial, slow-release NPK-fertilizer (Plantacote ${ }^{\mathrm{TM}}$ Depot 6M, Urania Agrochem, Hamburg), consisting of pellets with a semipermeable polyurethane layer. Monitoring of nutrient release rates in situ revealed a decline after $6 \mathrm{wk}$ (Worm et al. 2000b). Thus, the experiment was performed for Weeks 1 to 5 after replacement of the fertilizer. Fertilizer pellets were enclosed in polyethylene mesh rolls (diffusers) $4 \mathrm{~cm}$ in diameter and of variable length. The length of the diffusers and the amount of pellets corresponded to different nutrient enrichment levels (length of diffuser: 2.5, 5, 10, 20, 40 and $80 \mathrm{~cm}$; corresponding amount of pellets: 10, 20, 40, 80, 160, $320 \mathrm{~g}$ respectively). Treatments without nutrient enrichment were replicated 4-fold, each diffuser length was replicated 2-fold (see below, for statistical analysis).

To quantify nutrient release, we collected water samples with $30 \mathrm{ml}$ polyethylene syringes from all experimental plots after 2 wk (18 May 1998). Samples were immediately filtered (Acrodisc ${ }^{\mathrm{TM}} 5 \mu \mathrm{m}$ single-use filters, Gelman Sciences) and analysed for nitrate, nitrite, ammonium, orthophosphate and silicate with an autoanalyzer using the methods of Grasshoff et al. (1983). To quantify grazer densities we counted herbivores on all plots within $10 \times 10 \mathrm{~cm}$ quadrates (2 May 1998).

All treatments were arranged in a randomised block design with 2 blocks. Blocks measured $10 \times 30 \mathrm{~m}$ and were separated by $20 \mathrm{~m}$. Individual plots were separated by 3 to $4 \mathrm{~m}$ to avoid interactions among plots. As a standard substrate for benthic microalgal colonisation, we used heat-sterilised ceramic tiles $(5 \times 5 \mathrm{~cm})$ in order to eliminate the effect of different microtopography of the natural sites (Nicotri 1977). Microalgae were harvested after exposure for 23 d (9 May to 1 June 1998). The biomass was scraped off with a razor blade, suspended in $25 \mathrm{ml}$ filtered seawater $(0.2 \mu \mathrm{m}$ celluloseacetate filters) and fixed with Lugol's iodine. A subsample of the suspension was filled into Utermöhl counting chambers, and at least 1000 cells per sample were counted with an inverted microscope (Leitz DMIRB). We calculated biovolume for each species following Hillebrand et al. (1999). We determined species richness (S) and calculated Shannon-Wiener diversity index $\left(H^{\prime}\right)$ and Pielou's evenness index $\left(J^{\prime}\right)$ using bio- volume proportions. Combining these different estimates of diversity allowed us to make quantitative statements on changes in community structure (Hillebrand \& Sommer 2000).

We employed 2 different modes of analysis: (1) we tested for the main effects and interactions among the experimental factors by factorial ANOVA and MANOVA $_{i}(2)$ we modeled the quantitative response of microalgae to nutrient enrichment by linear-regression analysis. This combined design allows powerful hypotheses testing as well as quantitative predictions of nutrient effects (Worm et al. 2000a). Biovolume and diversity data were analysed by fixed-factor ANOVA, including grazer (presence vs absence) and nutrients (no, low, mid and high enrichment levels) as independent variables. In order to achieve a balanced ANOVA-design (Underwood 1997), we combined enrichment treatments into the categories no (no enrichment), low (2.5 and $5 \mathrm{~cm}$ diffusers), mid (10 and $20 \mathrm{~cm}$ diffusers) and high (40 and $80 \mathrm{~cm}$ diffusers). It should be noted that this ANOVA approach is conservative by combining different treatments. The block effect was analysed as a third, non-interactive variable. In order to test for changes in species composition following our experimental manipulations, we analysed the biovolume of individual species by MANOVA, using the Pillai trace statistic (Johnson \& Field 1993). The control experiment (open cages vs uncaged plots) was analysed in the same way as the main experiment, except that the factor 'cage' replaced the factor 'grazer'. Homogeneity of variances was checked using Bartlett's $\chi^{2}$ test (Sokal \& Rohlf 1995) for the ANOVA data and Sen-Puri's test for the multivariate procedure. Tukey's honest significant differences (HSD) test was employed as a posthoc test.

In the linear regression analysis, we examined the quantitative responses of microalgal biovolume to nutrient enrichment using all 7 nutrient treatments (corresponding to $0,2.5,5,10,20,40$ and $80 \mathrm{~cm}$ diffuser length). The significance of differences between slopes was tested with an F-test (Sokal \& Rohlf 1995). For the 20 most abundant species, we compared the effect of nutrients and grazing. We used Spearman's rank-correlation between the slope of the regression analysis (i.e. the rate of increase with nitrogen enrichment as a measure of nutrient impact) and the mean difference between grazed and ungrazed treatments as a measure of grazing loss.

Spring grazing experiment. In May 1998, grazerexclusion experiments were conducted at 3 different sites in order to reveal spatial variability of grazing pressure on benthic microalgae across different sites. The chosen sites were 3 sheltered embayments in the Western Baltic Sea: Maasholm $\left(54^{\circ} 45^{\prime} \mathrm{N}\right.$, $10^{\circ} 00^{\prime} \mathrm{E}$ ), Geltinger Noor and Wackerballig (both 
$\left.54^{\circ} 46^{\prime} \mathrm{N}, 9^{\circ} 53^{\prime} \mathrm{E}\right)$. These sites were similar to the main study site (see above) with respect to substrate availability, wave exposure, and water temperature. Grazer presence was manipulated as described above (closed and open cages, control plots without cage, each with 4 replicates, arranged in a randomised block design), but in this experiment we used small, circular cages (8 $\mathrm{cm}$ in diameter) covered with $1 \mathrm{~mm}$ clear polyethylene mesh. Grazer abundance at each site were determined using $25 \times$ 25 frames $(n=10$, Table 1$)$. In order to minimise potential variability caused by different recruitment of filamentous macroalgae, all tiles were seeded in the laboratory for $24 \mathrm{~h}$ with spores of the chlorophyte Enteromorpha intestinalis before they were exposed to the experimental plots. Colonisation of benthic microalgae on the tiles was analysed after $23 \mathrm{~d}$ exposure (6 to 29 May 1998), as described above. Biovolume data were analysed by fixed-factor ANOVAs including grazer presence and site as independent factors (cage and site in the control analysis). Data were log-transformed in order to assure homogeneity of variances (Bartlett's $\chi^{2}$-test).

Summer grazing experiment. In July 1998, grazerexclusion experiments were conducted at different sites in order to evaluate (1) whether herbivore effects on benthic microalgae vary between spring and summer, and (2) whether fishes can potentially affect microalgal colonisation through enhanced feeding on the herbivores (trophic cascades). This experiment was conducted at 2 of the 3 sites of the spring grazing experiment (Maasholm and Geltinger Noor). We used the same experimental setup as described for the spring grazing experiment (open and closed cages,

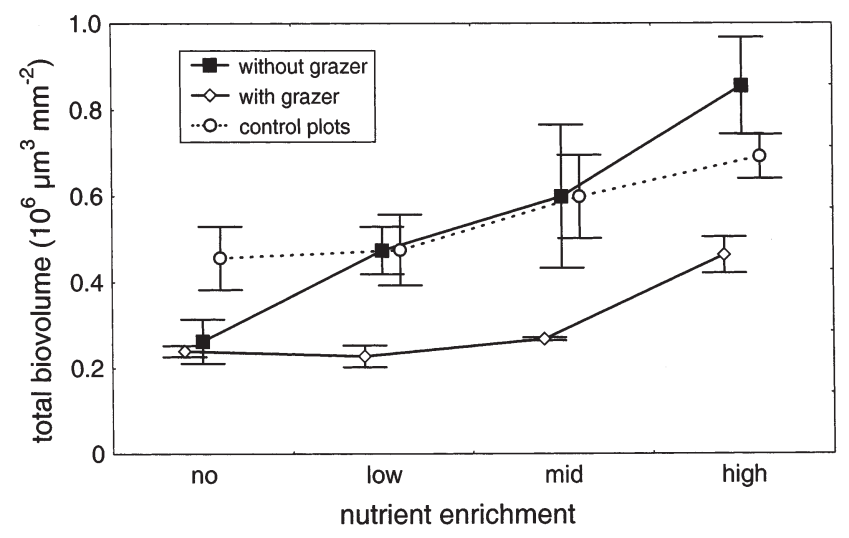

Fig. 1. Nutrient $\times$ grazing experiment. Total biovolume (mean $\pm \mathrm{SE}$ ) of benthic microalgae in relation to nutrient enrichment for closed cages (without grazer) and grazer-access cages (with grazer) as well as control plots. To calculate means, nutrient treatments were combined to no enrichment, low (diffuser length: 2.5 and $5 \mathrm{~cm}$ ), mid $(10$ and $20 \mathrm{~cm}$ ) and high (40 and $80 \mathrm{~cm}$ ) enrichment (4 replicates each) uncaged controls). Fish densities were low at these and 2 other surveyed sites $\left(<0.1 \mathrm{~m}^{-2}\right.$, counted by snorkeling along 5 replicate $30 \times 1 \mathrm{~m}$ transect strips parallel to shore at 0.5 to $1 \mathrm{~m}$ depth, Worm unpubl. data). Because of these low densities we chose to enhance encounter rates between fishes and periphyton, rather than to exclude fishes. For this, we exposed uncaged tiles at a distance of 10 to $20 \mathrm{~cm}$ near fish-burrows inhabited by individuals of Gobius niger, a common demersal fish that mainly feeds on small benthic and hyperbenthic invertebrates, including all major herbivores occuring at our experimental sites such as gastropods, isopods and amphipods ( $\mathrm{H}$. Thetmeyer pers. comm.). Colonisation of benthic microalgae on the tiles was analysed after $23 \mathrm{~d}$ of exposure (3 to 26 July 1998) as described above (spring grazing experiment). In addition, we compared uncaged control plots near and distant from fish burrows in a fixed-factor ANOVA with fish presence and site as the independent variables.

\section{RESULTS}

\section{Nutrient $\times$ grazing experiment}

During the nutrient $\times$ grazing experiment, background nutrient levels were $9.85 \mu \mathrm{mol} \mathrm{l^{-1 }}$ silicate, $0.16 \mu \mathrm{mol} \mathrm{l}^{-1}$ nitrate, $0.33 \mu \mathrm{mol} \mathrm{l^{-1 }}$ ammonium and $0.49 \mathrm{~mol} \mathrm{l}^{-1}$ phosphate, indicating strong nitrogen deficiency ( $\mathrm{N}: \mathrm{P} \ll 16)$. Nitrogen availability was significantly increased by NPK-fertilizer addition (ANOVA, ammonium: $p=0.006$; nitrate: $p=0.058)$, whereas phosphate and silicate concentrations were not significantly affected ( $p>0.45)$. Presence of grazers or cages had no significant effect on nutrient concentrations (ANOVA, p > 0.1). Ammonium and nitrate concentrations increased linearily with increasing diffuser length, and peaked at $1.45 \mu \mathrm{mol} \mathrm{l^{-1 }} \mathrm{NH}_{4}^{+}$(4.4-fold increase over background) and $0.47 \mu \mathrm{mol} \mathrm{l} \mathrm{l}^{-1} \mathrm{NO}_{3}^{-}$(2.9-fold increase).

Both grazer removal and nutrient enrichment significantly increased the total biomass of benthic microalgae (Fig. 1, Table 2). The presence of grazers reduced algal biomass in all nutrient treatments, but grazing effects were highest at high nutrient supply (Fig. 1). The microalgal biovolume increased linearily with nutrient enrichment in grazed and ungrazed treatments (Table 3), whereas the increase was significantly higher in the absence of herbivores (significant difference between slopes, $\left.F_{(1,28)}=6.45, \mathrm{p}<0.05\right)$. This indicated a stronger response of benthic microalgae to nutrients in the absence of grazers, although there was no significant grazing $\times$ nutrients interaction in the ANOVA (Table 2). 
Table 2. Nutrient $\times$ grazing experiment. Results of 2-way factorial ANOVA for total biovolume, with grazing and nutrient enrichment as independent factors, block as non-interactive variable, and total biovolume as dependent variable. Cage effect was analysed in an analogous analysis, with control plots replacing closed cages. Untransformed data gave normal distribution and homogeneity of variances

\begin{tabular}{|lrcrr|}
\hline Source of variation & (df) & MS & F-ratio & p-level \\
\hline Grazing effect & & & & \\
Grazer & $(1)$ & $4.933 \times 10^{11}$ & 22.306 & $<0.001$ \\
Nutrient enrichment & $(3)$ & $2.417 \times 10^{11}$ & 10.929 & $<0.001$ \\
Grazer $\times$ nutrients & $(3)$ & $0.523 \times 10^{11}$ & 2.365 & 0.097 \\
Block & $(1)$ & $0.715 \times 10^{11}$ & 3.230 & 0.085 \\
Error & $(23)$ & $0.221 \times 10^{11}$ & & \\
Cage effect & & & & \\
Cage & $(1)$ & $5.236 \times 10^{11}$ & 42.790 & $<0.001$ \\
Nutrient enrichment & $(3)$ & $0.882 \times 10^{11}$ & 7.206 & 0.001 \\
Cage $\times$ nutrients & $(3)$ & $0.029 \times 10^{11}$ & 0.241 & 0.867 \\
Block & $(1)$ & $0.388 \times 10^{11}$ & 3.173 & 0.088 \\
Error & $(23)$ & $0.122 \times 10^{11}$ & & \\
& & & & \\
\hline
\end{tabular}

The control experiment revealed significantly higher total biovolume in control plots than in open cages (Fig. 1, Table 2). This increase was due to the significant reduction of 1 species, Licmophora abbreviata, in the cages (Fig. 2). The higher biovolume of algae in the control plots was not related to grazer densities, which were lower in the open cages. The abundance of the slow-moving snail Littorina saxatilis was significantly lower in cages $\left(1084 \pm 238\right.$ ind. $\left.\mathrm{m}^{-2}\right)$ compared to control plots $(4031 \pm 408)$, which was most likely a result of our weekly brushing procedure. On the other hand, the cages slightly enhanced the densities of mobile gammarid amphipods (cage: $68 \pm 19$, control: 0) and isopods Idotea spp. (cage: $125 \pm 33$, control: $25 \pm$ 11).

The epilithic community consisted of 68 algal species, and was dominated by benthic diatoms; only small proportions ( $<5 \%$ of total biovolume) of cyanobacteria were present. Five species contributed $>90 \%$ to the total biovolume. Pronounced shifts in species composition occurred due to grazing (MANOVA, p = $0.0006)$ and nutrient enrichment $(p=0.0044)$. The centric diatom Melosira moniliformis was most susceptible to grazing, but was also most strongly favoured by nutrient enrichment (Fig. 2, Table 3). The increase of M. moniliformis with increasing nutrient enrichment was significantly steeper in the absence of grazers (significant difference between slopes, $F_{(1,28)}=43.98, \mathrm{p}<$ 0.001). M. nummuloides increased in grazer exclusion cages and at medium-to-high nutrient enrichment (Fig. 2), but the response to nutrient enrichment was non-linear (Table 3). The pennate diatom Tabularia fasciculata increased significantly with nutrient enrichment irrespective of herbivore presence or absence (Fig. 2, Table 3). The adnate-growing Cocconeis scutellum and the stalked Licmophora abbreviata were not significantly affected by grazing (Fig. 2). C. scutellum increased insignificantly with nutrient enrichment (Fig. 2), whereas L. abbreviata did not respond to nutrient enrichment. There was a clear positive correlation between the response to nutrient enrichment and grazer presence (Spearman rank-correlation, $\mathrm{p}<0.001$ ), i.e. species responding strongly to nitrogen enrichment faced also strong grazing losses.

Changes in community structure could also be perceived by changes in species richness and evenness (and thus diversity). Species richness was significantly decreased by grazer presence (ANOVA, p = 0.013), and increased with nitrogen supply, but this was not significant in the current experiment $(p=0.052)$. At all nutrient levels, species richness was lower in grazed than in ungrazed treatments (Fig. 3). The effect of grazing on diversity $\left(H^{\prime}\right)$ and evenness $\left(J^{\prime}\right)$ was not significant because of high variability in the grazerexclusion treatments (ANOVA, p > 0.3). However, $H^{\prime}$ (Fig. 3) and $J^{\prime}$ were both reduced by grazer presence at no and at low nutrient enrichment, whereas both indices were enhanced by grazer presence at mid and at high nutrient enrichment.

Table 3. Nutrient $\times$ grazing experiment. Linear regression analysis of nutrient-enrichment effects on total and species biovolume. Table gives regression slopes $b$ with standard error, significance of slope (ns: not significant, ${ }^{*} \mathrm{p}<0.05,{ }^{* *} \mathrm{p}<0.01,{ }^{* * *} \mathrm{p}<0.001$ ) and coefficient of determination $\left(\mathrm{r}^{2}\right)$

\begin{tabular}{|c|c|c|c|c|c|c|}
\hline \multirow[t]{2}{*}{ Dependent } & \multicolumn{2}{|c|}{ Without grazer } & \multicolumn{2}{|c|}{ With grazer } & \multicolumn{2}{|c|}{ Control plots } \\
\hline & $b \pm \mathrm{SE}$ & $\left(\mathrm{r}^{2}\right)$ & $b \pm \mathrm{SE}$ & $\left(\mathrm{r}^{2}\right)$ & $b \pm \mathrm{SE}$ & $\left(r^{2}\right)$ \\
\hline Total biovolume & $7688.2 \pm 2056.9^{* *}$ & $(0.499)$ & $3192.0 \pm 660.3^{* * *}$ & $(0.625)$ & $3126.6 \pm 1471.2^{\mathrm{ns}}$ & $(0.244)$ \\
\hline Tabularia fasciculata & $1293.8 \pm 376.5^{* *}$ & $(0.458)$ & $1199.5 \pm 150.6^{* * *}$ & $(0.819)$ & $1851.3 \pm 401.6^{* * *}$ & $(0.603)$ \\
\hline Cocconeis scutellum & $183.6 \pm 132.7^{\mathrm{ns}}$ & $(0.120)$ & $118.5 \pm 76.0^{\mathrm{ns}}$ & $(0.147)$ & $8.72 \pm 103.4^{\mathrm{ns}}$ & $(0.001)$ \\
\hline Melosira moniliformis & $5917.4 \pm 1792.4^{* *}$ & $(0.438)$ & $1095.6 \pm 465.2^{*}$ & $(0.284)$ & $466.6 \pm 194.6^{*}$ & $(0.291)$ \\
\hline Melosira nummuloides & $101.2 \pm 92.1^{\mathrm{ns}}$ & $(0.079)$ & $4.3 \pm 34.3^{\mathrm{ns}}$ & $(0.001)$ & $110.5 \pm 24.7^{* * *}$ & $(0.588)$ \\
\hline Licmophora abbreviata & $-100.7 \pm 427.6^{\mathrm{ns}}$ & $(0.004)$ & $591.9 \pm 358.9^{\mathrm{ns}}$ & $(0.163)$ & $812.0 \pm 1203.11^{\mathrm{ns}}$ & $(0.032)$ \\
\hline
\end{tabular}




\section{Spring grazing experiment}

Microalgal biomass differed significantly across sites, and grazers significantly reduced microalgal biovolume across all sites (Fig. 4, Table 4). Total biovolume was significantly higher in Maasholm than in
Geltinger Noor and Wackerballig (Tukey's HSD, p < 0.05). The impact of herbivores on microalgal biomass was also highest in Maasholm, but also evident in both other sites (ANOVA, planned comparison, $\mathrm{p}<0.05$ ). In this experiment, no cage artifact was detected (Table 4).
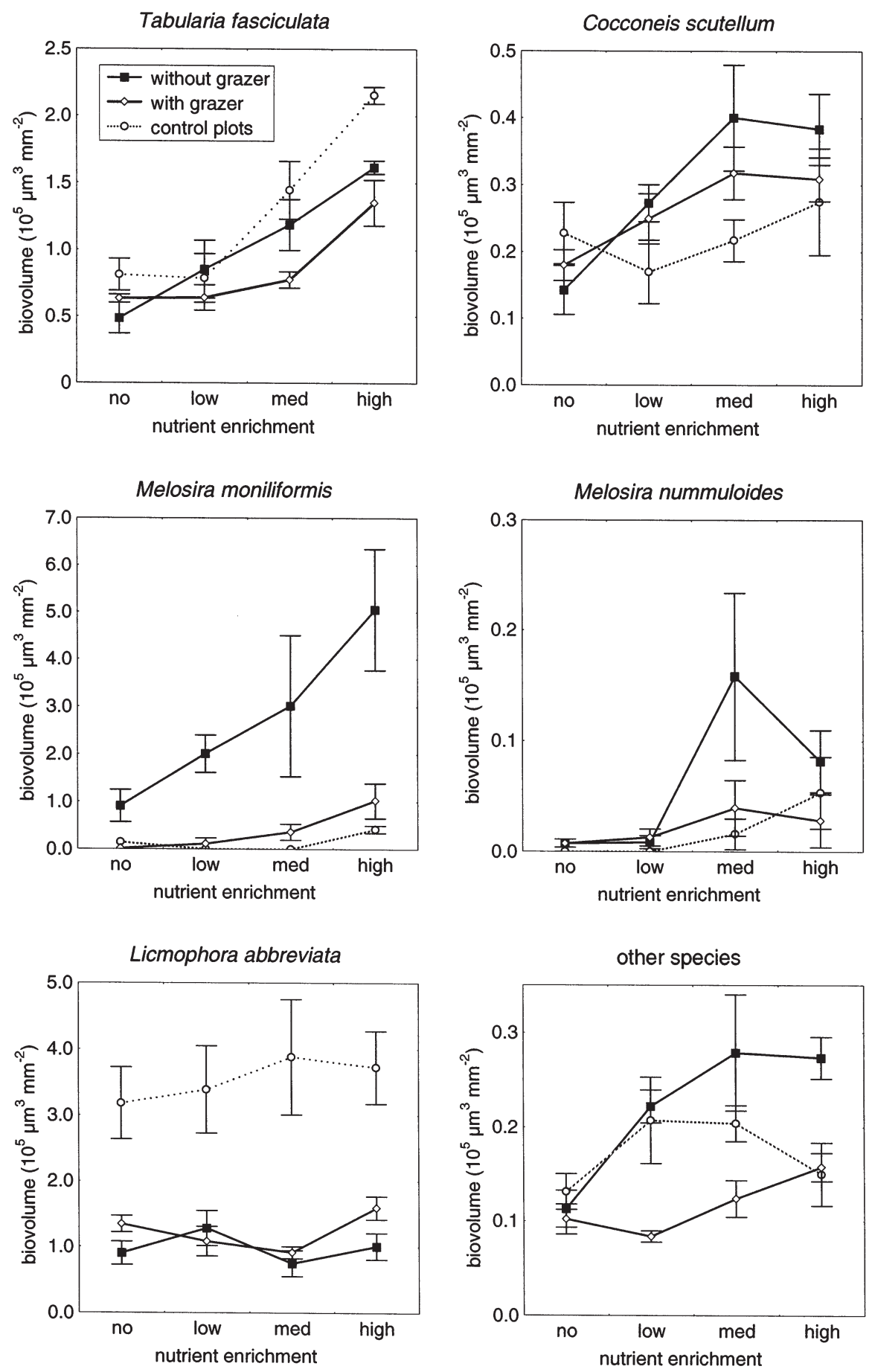

Fig. 2. Nutrient $\times$ grazing experiment. Species biovolume (mean $\pm \mathrm{SE}$ ) of benthic microalgae in relation to nutrient enrichment for closed cages (without grazer) and grazer-access cages (with grazer) as well as control plots. Plots represent 5 most abundant species and combined biovolume of the other species. Note differences in ordinate scales 


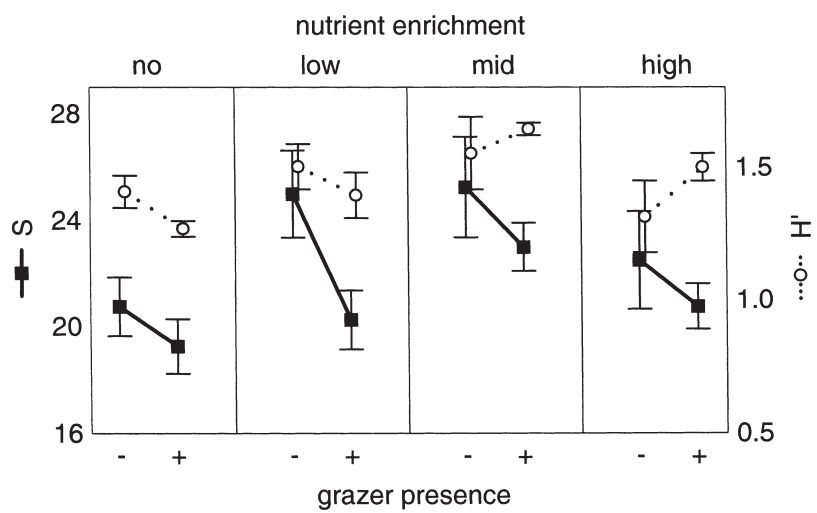

Fig. 3. Nutrient $\times$ grazing experiment. Species diversity (Shannon-Wiener Index, $H^{\prime}$ ) and species richness (S) of benthic microalgae in relation to nutrient enrichment (no, low, medium and high enrichment) and to grazer presence (-: closed cages without grazer; +: grazer-access cages with grazers)

Species composition was similar to the nutrient $x$ grazing experiment, with 51 species recorded and diatoms contributing $>90 \%$ to the total biovolume. The species composition was significantly influenced by the factors site (MANOVA, $\mathrm{p}=0.0014$ ) and grazer presence $(p<0.001)$, whereas the cages had no significant effect on species composition ( $p=0.351)$. Grazer exclusion significantly increased the biovolume of Berkeleya rutilans in Maasholm and Wackerballig and of Melosira moniliformis in Maasholm and Geltinger Noor (Fig. 5). Licmophora abbreviata contributed less to total biovolume in ungrazed treatments, whereas the proportions of Tabularia fasciculata and Cocconeis scutellum were not changed by grazer exclusion. Species number was significantly reduced by grazing at all 3 sites (ANOVA, $\mathrm{p}<0.001$ ), whereas $H^{\prime}$ and $J^{\prime}$ were unaffected (ANOVA, $\mathrm{p}>0.3$ ).

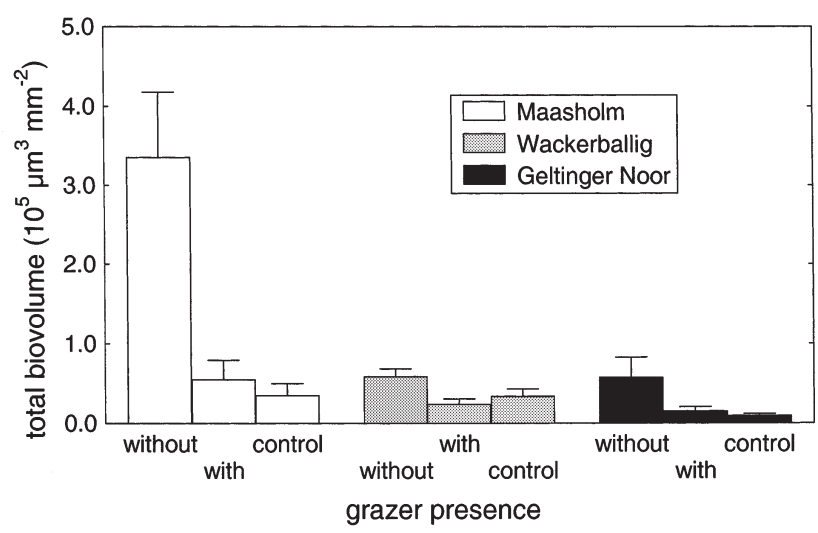

Fig. 4. Spring grazing experiment. Total biovolume (mean \pm $\mathrm{SE}$ ) of benthic microalgae in uncaged control plots, grazeraccess cages (with) and grazer-exclusion treatments (without)
Table 4. Spring grazing experiment. Results of 2-way ANOVA for total biovolume, with site and grazing as independent factors and log-transformed total biovolume as dependent variable. $\log _{10}$-transformation resulted in normal distribution and homogeneity of variances

\begin{tabular}{|lrrrr|}
\hline Source of variation & (df) & MS & F-ratio & p-level \\
\hline Grazing effect & & & & \\
Site & $(2)$ & 1.154 & 8.468 & 0.002 \\
Grazing & $(1)$ & 3.073 & 22.557 & $<0.001$ \\
Site $\times$ grazing & $(2)$ & 0.092 & 0.675 & 0.519 \\
Error & $(22)$ & 0.136 & & \\
Cage effect & & & & \\
Site & $(2)$ & 0.593 & 3.362 & 0.055 \\
Cage & $(1)$ & 0.009 & 0.052 & 0.822 \\
Site $\times$ cage & $(2)$ & 0.131 & 0.745 & 0.488 \\
Error & $(20)$ & 0.176 & & \\
\hline
\end{tabular}

\section{Summer grazing experiment}

In the summer experiment, no significant grazer effect on microalgal biovolume was detected (ANOVA, $p=0.21$ ). Total biovolume tended to be higher in Maasholm than in Geltinger Noor, but this was significant only for uncaged plots (Fig. 6). Manipulations of fish density had no significant effect on the total biovolume of the periphyton (ANOVA, $\mathrm{p}=0.832$ ) or on the presence of any dominant species. Neither diversity nor species richness were significantly affected by grazing (ANOVA, $\mathrm{p}>0.4$ ). No cage artifact was detected in the control experiment $(p=0.422)$. Fifty species were recorded in this experiment. The species composition was slightly altered compared to the spring grazing experiment carried out in May (Figs. 5 \& 7). In Maasholm, the proportion of cyanobacteria increased, and the diatom community was shifted to a higher contribution of small, mobile diatoms, e.g. Cylindrotheca closterium and Navicula cf. perminuta. However, Licmophora abbreviata, Tabularia fasciculata and Cocconeis scutellum were still among the most abundant species (Fig. 7). Neither grazing nor cage presence had significant effects on species composition (MANOVA, grazing: $p=0.357$; cage presence: $\mathrm{p}=0.589)$.

\section{DISCUSSION}

We have demonstrated strong and antagonistic effects of grazers and nitrogen supply on biomass, species composition and diversity in a benthic microalgal community. Nitrogen enrichment led to increased algal biovolume, but grazers also removed more bio- 


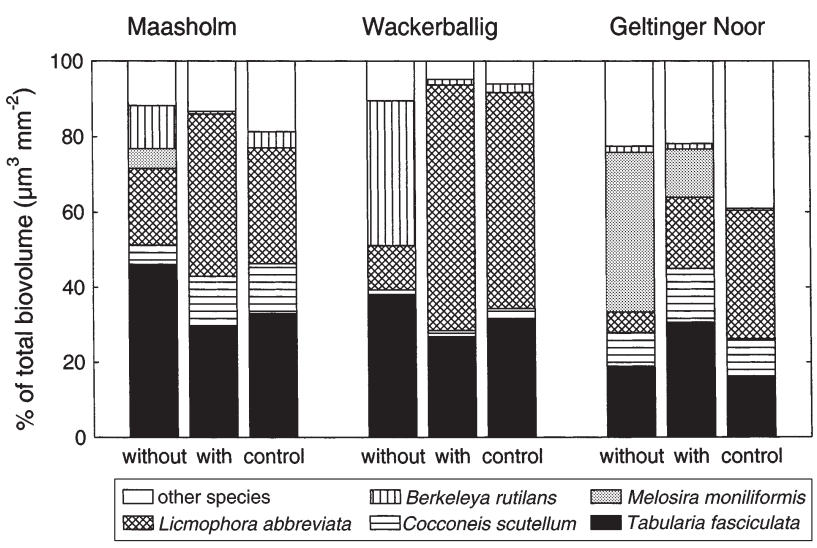

Fig. 5. Spring grazing experiment. Species composition of benthic microalgae presented as mean percent contribution to total biovolume, in uncaged control plots, grazer-access cages (with) and grazer-exclusion (without) treatments

mass at enriched nutrient levels. A trade-off between resource use and susceptibility to herbivores, depending on microalgal growth form, led to antagonistic effects of grazing and nutrient effects on periphytic community structure. The grazing effects were variable between similar sites and between seasons.

\section{Effects on total biovolume}

In both, the nutrient $\times$ grazing and the spring grazing experiment, grazers influenced biomass and species composition of benthic microalgae. This is consistent with previous studies on periphyton from marine (Castenholtz 1961, Nicotri 1977, Hunter \& Russell-Hunter 1983) and freshwater (Hill \& Knight 1987, Steinman 1996) habitats.

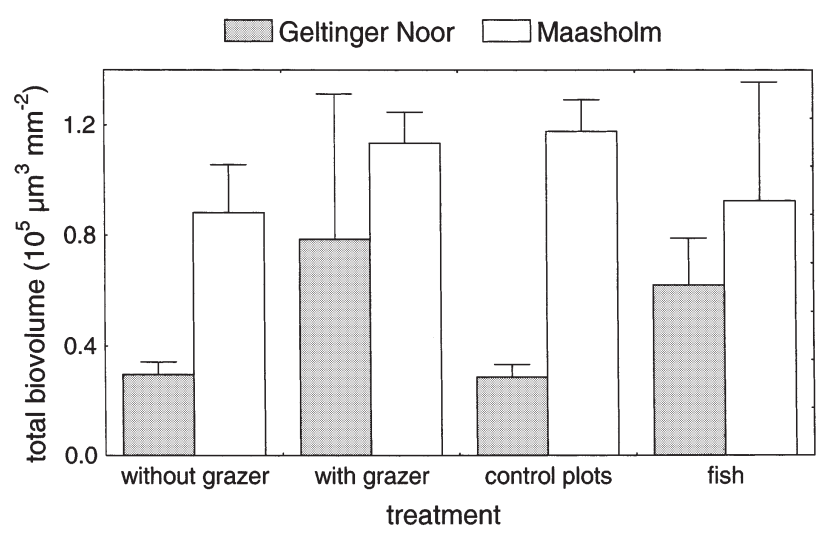

Fig. 6. Summer grazing experiment. Total biovolume (mean \pm $\mathrm{SE}$ ) of benthic microalgae in uncaged control plots, grazeraccess cages (with grazer), grazer-exclusion cages (without grazer), and uncaged plots near fish burrows (fish)
The effects of grazing and nitrogen enrichment on microalgal biomass were antagonistic. Grazers removed a significant part of microalgal biomass in all enriched treatments, but not in unenriched controls (Fig. 1). In enriched treatments, benthic microalgal biovolume increased, but at the same time consumption was enhanced. Thus the effect of nutrient enrichment was dampened in the presence of grazers (Table 3). In grazed treatments, the biovolume of benthic microalgae predominantly increased at the highest nutrient levels, indicating that the algae started to outgrow their losses at the highest nutrient supply. This may also indicate incipient saturation of the functional response of the herbivores. A Type-II functional response in dependence of prey density was described for the periwinkle Littorina littorea, and can be assumed also for other gastropods (Sommer 1999a). The curvilinear relationship suggests that grazers are ineffective in low nutrient-low biomass environments. Nitrogen enrichment in our experiment allowed benthic microphytes to grow faster, but at the same time enabled herbivores to consume more biomass. Increased grazing effects in nutrient-enriched versus unenriched plots have also been described from freshwater experiments (Marks \& Lowe 1989, Rosemond et al. 1993). Thus, the bottom-up effect of nutrient enrichment influenced the trophic levels of producer and consumer simultaneously. Numerical responses of herbivores could not be tested because of the short time scale of our experiments.

Furthermore, grazers decreased the variability of benthic microalgal biomass in nutrient-enriched treatments (Fig. 1) and the variability of community structure (e.g. diversity, Fig. 3). A similar pattern has been observed for filamentous macroalgae (mainly Enteromorpha intestinalis), which showed decreased biomass variability in grazed versus ungrazed treatments (Lotze unpubl. data). In contrast, Sommer (1999b) found increased spatial heterogeneity of benthic microalgae due to grazing by Littorina littorea, which was attributed to the bulldozer-like grazing type of this gastropod. However, the abundance of L. saxatilis in our experiments was an order of magnitude higher than in Sommer's experiment (1999b). This high grazer density may lead to substantial overlap of grazing tracks and a homogenisation of the algal assemblage, favouring prostrate algae and resulting in an uniform prostrate algal assemblage, without vertical gradients of light and nutrient availability. Herbivores may thus compensate the variability introduced by stochastic germination and colonisation processes (Hart 1992) and differences in maximum growth rates under nutrient-enriched conditions.

Spatial and seasonal variability of biotic interactions among 3 sheltered embayments was evident in our 


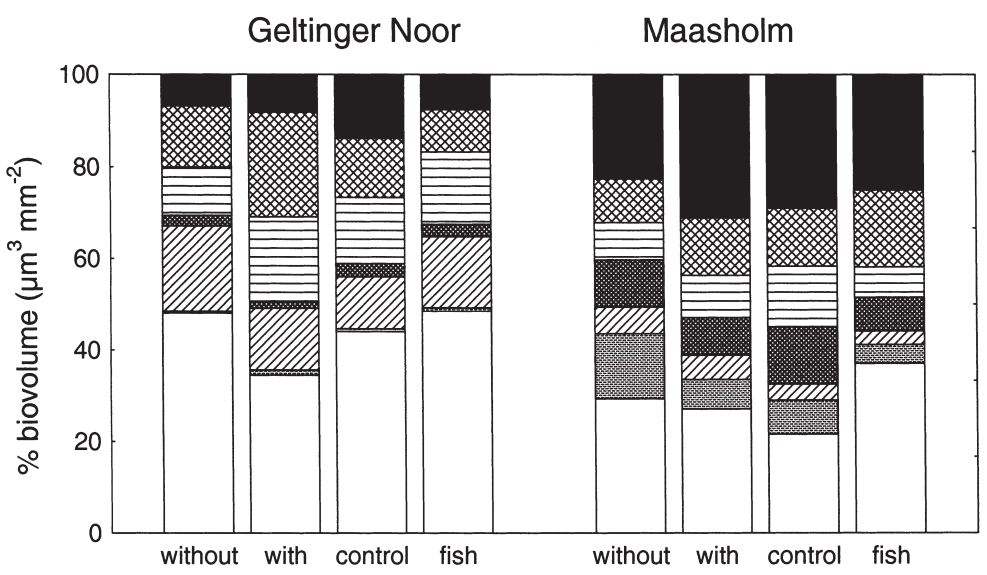

Tabularia fasciculata Licmophora abbreviata $\Xi$ Cocconeis scutellum

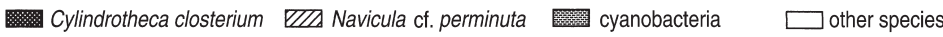

Fig. 7. Summer grazing experiment. Species composition of benthic microalgae, presented as mean percent contribution to total biovolume, for uncaged control plots, grazer-access cages (with), grazer-exclusion cages (without) and uncaged plots near fish burrows (fish)

experiments. Maasholm showed strongest grazing control, which can be explained by higher herbivore densities at this site, especially for the gastropod Littorina saxatilis (Table 1). Increased abundance of L. saxatilis may also explain the higher grazing effect in Geltinger Noor than in Wackerballig (Fig. 4, Table 1). Lotze (1998) showed that $L$. saxatilis feeds heavily on filamentous macroalgal germlings (Enteromorpha spp., Pilayella littoralis), whereas this grazer species did not feed on the adult stages. Macroalgal germlings are in the same size order as the benthic microphytes in our experiments. Decreasing herbivore abundance, especially of L. saxatilis, may also explain the seasonal shift of grazing impact from May to July in Maasholm. This variability in grazing pressure may be caused by changes in the prey or in the predator community. Herbivores are likely to become food-limited in summer, because reduced nitrogen availability reduces the biomass and the nutritional value of the benthic algae (Hillebrand \& Sommer 1997). Increasing predation may also affect herbivore densities during summer. However, we did not find any evidence for a trophic cascade in our experiment. Three- to 4-level trophic cascades are known from freshwater pelagic (McQueen et al. 1989), periphyton (Dahl 1998, McCollum et al. 1998) and marine macrobenthic communities (Estes et al. 1998). In our summer experiment, fish and herbivore abundances were possibly too low to detect cascading effects in lower trophic levels.

Cage effects on total algal biovolume were detected in the nutrient $\times$ grazing experiment, but in none of the other 2 experiments. In the nutrient $\times$ grazing experi- ment, microalgal biovolume was higher in control plots than in grazer-access cages, although total grazer abundance was lower in the cages. The higher biovolume was a result of increased abundance of the pennate diatom Licmophora abbreviata. Licmophora species often belong to the first and prominent colonisers in the Western Baltic Sea, and they often settle on thin, finely branched macroalgae (Ramm 1977). Decreased biomass of $L$. abbreviata in caged plots may be attributed to a high proportion of $L$. abbreviata settling on the mesh, thereby reducing the number of settlers within cages. This interpretation is supported by the high proportion of $L$. abbreviata in the nutrient $\times$ grazing experiment (mean percent in unenriched control plots: 69.7) compared to the experiments without significant cage effects (spring: Maasholm $30.8 \%$, Wackerballig 57.3\%, Geltinger Noor $34.2 \%$; summer: Maasholm $12.7 \%$, Geltinger Noor $12.8 \%$ ). In agreement with this assumption, there was a decrease in total biovolume in caged versus uncaged plots in the experiment with the next highest proportion of L. abbreviata (Wackerballig; spring grazing experiment: Fig. 5).

\section{Effects on species composition}

In the absence of gut analysis and other direct measurements of choice, selectivity of grazers for different algal species or growth types can only be inferred from the species composition of the prey community. Herbivores can alter species composition by actively preferring food items (active choice), by passively ingesting more of the species which are structurally more available (passive preference), or by changing the competitive outcome between prey species by increasing mortality rates or nutrient supply via regeneration.

Within our experiments, erect, chain-building microalgal species (e.g. Melosira moniliformis and M. nummuloides) were preferred by herbivores. These species contributed 35 to $60 \%$ to the total biovolume in grazerexclusion treatments of the nutrient $\times$ grazing experiment, but $<20 \%$ in treatments with grazer access. Herbivore preference of loosely attached, upperstory microalgae is a very consistent pattern in freshwater periphyton (Hill \& Knight 1987, Steinman et al. 1991). Although several species (especially M. moniliformis, M. nummuloides) were preferentially removed by herbivores, this does not indicate active choice at the species level. Reviewing freshwater grazing experiments, Steinman (1996) concluded that active choice may not 
occur in many macrozoobenthic herbivores because of the low prey:grazer size ratio, the apparent lack of specialized uptake mechanisms, and the putative absence of sensory equipment (but see freshwater insect larvae: Feminella \& Resh 1991). Nicotri (1977) showed that 4 sympatric gastropod species preferentially ingested species that were among the least digestable (M. moniliformis and M. nummuloides). The increased proportion of the 2 Melosira species in the gastropods' diet was apparently not caused by active choice, but by a functional preference depending on cell volume, growth form, and strength of attachment. This is also suggested by the grazing loss of the tube-dwelling diatom Berkeleya rutilans in the spring grazing experiment. The gelatinous tubes built by $B$. rutilans decrease its nutritional value, but it may have a higher probability of being removed because of its erect growth form. In laboratory experiments, B. rutilans was grazed at low rates by the isopod Idotea chelipes and the periwinkle Littorina littorea (Sommer 1997, 1999a). The mechanical activity of the grazer (Castenholtz 1961, Sumner \& McIntire 1982) causes removal rates which are much higher than the ingestion rates (Cattaneo \& Mousseau 1995). In our in situ experiments, dislodging led to a loss from the community, whereas in the laboratory experiments the algae can survive (Sommer 1999a). This could explain the different impact of grazing on $B$. rutilans in situ and in the laboratory.

Growth form may also explain the low grazing impact on the adnate species Cocconeis scutellum, which also positively responded to the presence of grazers in freshwater experiments (Colletti et al. 1987, Pan \& Lowe 1994). Grazer-resistance of Licmophora abbreviata, however, was more surprising, since the congeneric species L. ehrenbergii was heavily grazed by Idotea chelipes (Sommer 1997). But this species may easily be ingested only if it is growing as an epiphyte in the canopy layer (Sommer 1999c). In our experiments, L. abbreviata was rarely observed in multicellular aggregations or epiphytically. Possibly, the flexibility of the stalk made the attachment of $L$. abbreviata more resistant to mechanical forces provided by the radula of gastropods compared to the more picking grazing mode of isopods (Sommer 1997). The relative increase of $L$. abbreviata in the presence of grazers may also be due to competitive release, as previously described for other groups, e.g. cyanobacteria (McCormick \& Stevenson 1991, Rosemond et al. 1993).

Melosira moniliformis was not only the species least resistant against herbivory, but, simultaneously, it was also the species with the highest response to nutrient enrichment in the nutrient $\times$ grazing experiment (Table 3). This is in accordance with results from the nearby Kiel Fjord, where this species was highly favoured by nitrogen additions in summer and fall (Hillebrand \& Sommer 1997). As in the experiments from the Kiel Fjord, Tabularia fasciculata was also favoured by high nutrient levels, whereas Licmophora abbreviata was unaffected (absolute biovolume) or reduced (relative biovolume).

Considering the combined impacts of nutrients and herbivores, a positive correlation between nutrient use efficiency and susceptibility to grazing became evident. Sommer (1997) showed a similar correlation between growth rate and grazing mortality in laboratory experiments with epilithic microalgae. We conclude that there is an apparent allocation trade-off between grazing resistance and nutrient uptake. Growth versus resistance trade-offs are a general pattern in plant communities. For macroalgae, Littler \& Littler (1980) demonstrated an inverse relationship between thallus toughness and grazing resistance versus growth rate. For higher plants, the trade-off between resistance and growth is often linked to the allocation of resources to chemical defence compounds (Coley et al. 1985, Bazzaz et al. 1987). For benthic microalgae, this trade-off is presumably not related to the production of defence compounds or toughness, but to growth-form constraints: erect species do not resist mechanical forcing (e.g. grazing), but can access nutrients from the water column overlying the nutrient-depleted periphyton (Riber \& Wetzel 1987, Paul \& Duthie 1989, Steinman et al. 1992, Rosemond et al. 1993, Hillebrand \& Sommer 1997). Microalgae which live adnate to the surface are more resistant to mechanical force (Poff \& Ward 1995, Steinman 1996), but are isolated from the water column as a nutrient source (Burkholder et al. 1990).

\section{Effects on diversity}

Diversity is a composite parameter integrating the number of species and the distribution of biomass among these species. In our experiments, both aspects were affected by grazing in different ways. Grazing significantly reduced the species richness in the nutrient $\times$ grazing experiment and also in the spring grazing experiment, a situation frequently is observed in freshwater experiments (Steinman 1996). The impact of grazer presence on diversity and evenness was not significant, but nevertheless consistent: grazer presence decreased both indices during low nutrient supply but increased both during high nutrient supply. Similarily, a recent metaanalysis implies that grazing tends to reduce plant species richness at oligotrophic sites, but enhances richness at eutrophic sites (Proulx \& Mazumder 1998). These contrasting effects 
are based on the increased dominance of only a few species following nutrient enrichment, and the preferential removal of such opportunistic but grazersusceptible species by herbivores (Lubchenco 1978, Proulx et al. 1996, Proulx \& Mazumder 1998). This pattern is consistent with the trade-off between growth and grazing resistance observed in our experiments. Despite the local extinction of species, grazing increases diversity by increasing evenness if dominant species are most edible (Lubchenco 1978), but decreases diversity if subdominant species are preferred (Swamikannu \& Hoagland 1989).

These results emphasize that eutrophication effects on plant community structure are consumer-dependent (Proulx \& Mazumder 1998, Worm et al. 1999, 2000a). Effective herbivore guilds can modulate the impact of enhanced resource supply on autotrophs, based on the fact that species responding positively to nutrient enrichment are sufficiently edible, which seems to be a general pattern in plant communities. Without losses due to grazing, maximum diversity is assumed to occur at low nutrient concentrations (Tilman 1982, Huston \& de Angelis 1994). In grazed communities, highest diversity may be established at higher resource levels which compensate losses to grazing. Other mortality factors such as disturbances have similar effects on periphytic diversity (Biggs et al. 1998). Periphyton assemblages were shown to be good model systems for studying the dependency of species diversity on nutrient supply and consumer density.

Acknowledgements. This work profited from comments and support by Ulrich Sommer, Ulrike-G. Berninger, Monika Feiling and Rolf Karez. We appreciate the statistical advice given by Peter S. Petraitis, and improvements to the manuscript by Stephanie Reuss and Thorsten Blenckner. H.H. acknowledges financial support from the Deutsche Forschungsgemeinschaft (DFG-So-145/15-1 and 15-2), B.W. and H.K.L. received grants from the German Ministry of Education (HSP III).

\section{LITERATURE CITED}

Bazzaz FA, Chiariello NR, Coley PD, Pitelka LF (1987) Allocating resources to reproduction and defence. Bio Sci 37: $58-67$

Biggs BJF, Stevenson RJ, Lowe RL (1998) A habitat matrix conceptual model for stream periphyton. Arch Hydrobiol 143:21-56

Burkholder JM, Wetzel RG, Klomparens KL (1990) Direct comparison of phosphate uptake by adnate and loosely attached microalgae within an intact biofilm matrix. Appl Environ Microbiol 56:2882-2890

Castenholtz RW (1961) The effect of grazing on marine littoral diatom populations. Ecology 42:783-794

Cattaneo A, Mousseau B (1995) Empirical analysis of the removal rate of periphyton by grazers. Oecologia 103: $249-254$
Coley PD, Bryant JP, Chapin FS (1985) Resource availability and plant antiherbivore defence. Science 230:895-899

Colletti PJ, Blinn DW, Pickart A, Wagner VT (1987) Influence of different densities of the mayfly grazer Heptagenia criddlei on lotic diatom communities. J N Am Benthol Soc 6:270-280

Daehnick AE, Sullivan MJ, Moncreiff CA (1992) Primary production of the sand microflora in seagrass beds of Mississippi Sound. Bot Mar 35:131-139

Dahl J (1998) Effects of a benthivorous and a drift-feeding fish on a benthic stream assemblage. Oecologia 116:426-432

Estes JA, Tinker MT, Williams TM, Doak DF (1998) Killer whale predation on sea otters linking oceanic and nearshore ecosystems. Science 282:473-476

Feminella JW, Resh VH (1991) Herbivorous caddisflies, macroalgae and epilithic microalgae: dynamic interactions in a stream grazing system. Oecologia 87:247-256

Grasshoff K, Erhardt M, Kremling K (1983) Methods of seawater analysis. 2nd edn. Verlag Chemie, Weinheim

Hart DD (1992) Community organization in streams: the importance of species interactions, physical factors, and chance. Oecologia 91:220-228

Hill WR, Knight AW (1987) Experimental analysis of the grazing interaction between a mayfly and stream algae. Ecology 68:1955-1965

Hillebrand H, Sommer U (1997) Response of epilithic microphytobenthos of the Western Baltic Sea to in situ experiments with nutrient enrichment. Mar Ecol Prog Ser 160: $35-46$

Hillebrand H, Sommer U (2000) Diversity of benthic microalgae in repsonse to colonization time and eutrophication. Aquat Bot 67:221-236

Hillebrand H, Dürselen CD, Kirschtel D, Zohary T, Pollingher U (1999) Biovolume calculation for pelagic and benthic microalgae. J Phycol 35:403-424

Hunter RD, Russell-Hunter WD (1983) Bioenergetic and community changes in intertidal Aufwuchs grazed by Littorina littorea. Ecology 64:761-769

Huston MA, de Angelis DL (1994) Competition and coexistence: the effects of resource transport and supply rates. Am Nat 144:954-977

Johnson CR, Field CA (1993) Using fixed-effects model multivariate analysis of variance in marine biology and ecology. Oceanogr Mar Biol Annu Rev 31:177-221

Littler MM, Littler DS (1980) The evolution of thallus form and survival strategies in benthic marine macroalgae: field and laboratory tests of a functional form model. Am Nat $116: 25-44$

Lotze HK (1998) Population dynamics and species interactions in macroalgal blooms: abiotic versus biotic control at different life-cycle stages. Ber Inst MeeresKde Kiel 303

Lotze HK, Worm B, Sommer U (2000) Propagule banks, herbivory and nutrient supply control population development and dominance patterns in macroalgal blooms. Oikos 89:46-58

Lowe RL, Hunter RD (1988) Effect of grazing by Physa integra on periphyton community structure. J N Am Benthol Soc $7: 29-36$

Lubchenco J (1978) Plant species diversity in a marine intertidal community: importance of herbivore food preference and algal competitive abilities. Am Nat 112:23-39

Marks JC, Lowe RL (1989) The independent and interactive effects of snail grazing and nutrient enrichment on structuring periphyton communities. Hydrobiologia 185:9-17

McCollum EW, Crowder LB, McCollum SA (1998) Complex interactions of fish, snails, and littoral zone periphyton. Ecology 79:1980-1994 
McCormick PV, Stevenson RJ (1991) Grazer control of nutrient availability in the periphyton. Oecologia 86: 287-291

McQueen DJ, Johannes MRS, Post JR, Stewart TJ, Lean DR (1989) Bottom-up and top-down impacts on freshwater pelagic community structure. Ecol Monogr 59:289-309

Nicotri ME (1977) Grazing effects of four marine intertidal herbivores on the microflora. Ecology 58:1020-1032

Pan Y, Lowe RL (1994) Independent and interactive effects of nutrients and grazers on benthic algal community structure. Hydrobiologia 291:201-209

Paul BJ, Duthie HC (1989) Nutrient cycling in the epilithon of running waters. Can J Bot 67:2302-2309

Pinckney J, Zingmark RG (1993) Modeling the annual production of intertidal benthic microalgae in estuarine ecosystems. J Phycol 29:396-407

Poff NL, Ward JV (1995) Herbivory under different flow regimes: a field experiment and test of a model with a benthic stream insect. Oikos 72:179-188

Proulx M, Mazumder A (1998) Reversal of grazing impact on plant species richness in nutrient-poor vs nutrient-rich ecosystems. Ecology 79:2581-2592

Proulx M, Pick FR, Mazumder A, Hamilton PB, Lean DRS (1996) Experimental evidence for interactive impacts of human activities on lake algal species richness. Oikos 76: 191-195

Ramm G (1977) Structure of epiphytic diatom populations of the phytal of the Kiel Bight (Western Baltic). Beih Nova Hedwigia 54:379-387

Riber HH, Wetzel RG (1987) Boundary-layer and internal diffusion effects on phosphorus fluxes in lake periphyton. Limnol Oceanogr 32:1181-1194

Rosemond AD (1993) Interactions among irradiance, nutrients, and herbivores constrain a stream algal community. Oecologia 94:585-594

Rosemond AD, Mulholland PJ, Elwood JW (1993) Top-down and bottom-up control of stream periphyton: effects of nutrients and herbivores. Ecology 74:1264-1280

Schramm W, Lotze HK, Schories D (1996) Eutrophication and macroalgal blooms in inshore waters of the German Baltic coast: the Schlei Fjord, a case study. In: Rijstenbil JW, Kamermans P, Nienhuis PH (eds) EUMAC - synthesis report. NIOO, Yerseke, p 17-73

Sokal RR, Rohlf FJ (1995) Biometry. The principles and practice of statistics in biological research, 3rd edn. WH Freeman \& Company, New York

Sommer U (1997) Selectivity of Idothea chelipes (Crustacea, Isopoda) grazing on benthic microalgae. Limnol Oceanogr 42:1622-1628

Sommer U (1999a) The susceptibility of benthic microalgae to

Editorial responsibility: Otto Kinne (Editor),

Oldendorf/Luhe, Germany periwinkle (Littorina littorea, Gastropoda) grazing in laboratory experiments. Aquat Bot 63:11-21

Sommer U (1999b) The impact of herbivore type and grazing pressure on benthic microalgal diversity. Ecol Lett 2:65-69

Sommer U (1999c) Periphyton architecture and susceptibility to grazing by periwinkles (Littorina littorea, Gastropoda). Int Rev Ges Hydrobiol 84:197-204

Steinman AD (1996) Effects of grazers on benthic freshwater algae. In: Stevenson RJ, Bothwell ML, Lowe RL (eds) Algal ecology-freshwater benthic ecosystems. Academic Press, San Diego, p 341-373

Steinman AD, McIntire CD, Gregory SV, Lamberti GA, Ashkenas LR (1987) Effect of herbivore type and density on taxonomic structure and physiognomy of algal assemblages in laboratory streams. J N Am Benthol Soc 6: 175-188

Steinman AD, Mulholland PJ, Kirschtel DB (1991) Interactive effects of nutrient reduction and herbivory on biomass, taxonomic structure, and $\mathrm{P}$ uptake in lotic periphyton communities. Can J Fish Aquat Sci 48:1951-1959

Steinman AD, Mulholland PJ, Hill WR (1992) Functional responses associated with growth forms in stream algae. J N Am Benthol Soc 11:229-243

Sumner WT, McIntire CD (1982) Grazer-periphyton interactions in laboratory streams. Arch Hydrobiol 93:135-157

Sundbäck K, Snoeijs P (1991) Effects of nutrient enrichment on microalgal community composition in a coastal shallow-water sediment system: an experimental study. Bot Mar 34:341-358

Swamikannu X, Hoagland KD (1989) Effects of snail grazing on the diversity and structure of a periphyton community in a eutrophic pond. Can J Fish Aquat Sci 46:1698-1704

Tilman D (1982) Resource competition and community structure. Princeton University Press, Princeton

Tuchman NC, Stevenson RJ (1991) Effects of selective grazing by snails on benthic algal succession. J N Am Benthol Soc 10:430-443

Underwood AJ (1997) Experiments in ecology. Cambridge University Press, Cambridge

Worm B, Lotze HK, Boström C, Engkvist R, Labanauskas V, Sommer U (1999) Marine diversity shift linked to interactions among grazers, nutrients and propagule banks. Mar Ecol Prog Ser 185:309-314

Worm B, Lotze HK, Sommer U (2000a) Coastal food-web structure, carbon storage and nitrogen retention regulated by consumer pressure and nutrient loading. Limnol Oceanogr 45:339-349

Worm B, Reusch TBH, Lotze HK (2000b) In situ nutrient enrichment: methods for marine benthic ecology. Int Rev Ges Hydrobiol 85:359-375

Submitted: January 11, 2000; Accepted: April 20, 2000

Proofs received from author(s): September 4, 2000 